\title{
Pemertahanan Bahasa Tontemboan di Kalangan Pemuda Desa Mokobang Kecamatan Modoinding Kabupaten Minahasa Selatan
}

\author{
Brenda C. Otay, Nikolas Pesik, Nontje J. Pangemanan \\ Jurusan Pendidikan Bahasa dan Sastra Indonesia, Fakultas Bahasa dan Seni Universitas Negeri \\ Manado \\ brendaotay@gmail.com,nikolaspesiky@gmail.com,nontjepangemanany@gmail.com
}

\begin{abstract}
Abstrak. Masalah yang dihadapi bahasa Tontemboan Mokobang saat ini adalah kuatnya pengaruh bahasa melayu Manado (BMM) sehingga frekuensi berbahasa daerah pemuda sudah sangat menurun hal ini sangat mempengaruhi pemertahanan bahasa Tontemboan dikalangan pemuda. Tujuan penelitian ini ialah untuk mendeskripsikan penggunaan bahasa Tontemboan di kalangan pemuda Desa Mokobang Kecamatan Modoinding Kabupaten Minahasa Selatan. Metode yang digunakan dalam penelitian ini adalah metode deskriptif kualitatif. Sumber data penelitian ialah pemuda berusia 15-30 tahun. Untuk mengumpulkan data, teknik yang digunakan adalah teknik simak, teknik cakap, teknik catat serta teknik rekam. Hasil penelitian menunjukkan bahwa BT masih bertahan ketika BT digunakan terhadap orang yang lebih tua dalam situasi baik akrab maupun tidak akrab, juga terhadap oran yang berusia sebaya/lebih muda dan akrab dengan remaja.
\end{abstract}

Kata Kunci: Pemertahanan, B ahasa Tontemboan, Kalangan Pemuda

\section{PENDAHULUAN}

Masyarakat Indonesia merupakan masyarakat multilingual. Dikatakan demikian karena selain menguasai bahasa ibu yaitu bahasa daerah juga menguasai bahasa lainnya seperti bahasa melayu Manado dan bahasa Indonesia, bahkan menguasai bahasa asing. Masing-masing bahasa digunakan sesuai fungsinya. Bahasa Indonesia digunakan pada situasi formal seperti pidato, MC, ceramah ilmiah, berbicara dengan orang yang dihormati, untuk kepentingan perencanaan nasional. Bahasa daerah juga digunakan sebagai alat komunikasi penting di daerah misalnya berbelanja di pasar, acara adat perkawinan, menyambut tamu dan sebagainya. Bahasa asing juga memiliki fungsi tertentu meskipun fungsinya tidak semua penting dengan bahasa Indonesia dan daerah.

Dalam masyarakat multilingual, apalagi ditunjang oleh mobilitas masyarakat yang cukup tinggi, bukan hal yang mustahil akan terjadi kontrak bahasa. sebagaimana dikatakan oleh Chaer (2010: 219).

Masyarakat multilingual yang mobilitasnya tinggi, anggota-anggota masyarakat akan cenderung menggunakan dua bahasa atau lebih yang dikuasainya, baik secara keseluruhan ataupun hanya sebagian saja. Masyarakat terbuka, yaitu masyarakat yang dapat menerima kehadiran anggota masyarakat lain di dalam lingkungannya akan terjadinya apa yang dikatakan kontak bahasa (Chaer, 2010).

Provinsi Sulawesi Utara dikenal memiliki bahasa beraneka ragam. Kekayaan bahasa ini ditunjang oleh keberadaan Kabupaten Minahasa Selatan yang terdiri dari berbagai suku dan masing - masing suku memiliki bahasa daerahnya yang hingga saat ini masih aktif digunakan selain bahasa Indonesia yang berkedudukan sebagai bahasa negara dan bahasa nasional di Indonesia.

Salah satu bahasa di Kabupaten Minahasa Selatan adalah bahasa Tontemboan yang masih aktif digunakan oleh masyarakatnya di Kecamatan Modoinding desa Mokobang. Secara umum, masyarakat di desa Mokobang dalam berinteraksi sosial dengan warga lainnya menggunakan dua bahasa, yaitu bahasa Melayu Manado dan bahasa Tontemboan digunakan oleh masyarakat setempat dalam berkomunikasi dengan sesama etnis Minahasa Selatan. Misalnya ketika melakukan transaksi 
jual beli di pasar, berinteraksi di sekolah pada situasi nonformal, di jalan, di tempat ibadah, acara adat, da sebagainya. Bahasa Tontemboan ini masih aktif digunakan oleh orang tua dan orang dewasa. Kalangan remaja sebagian masih dapat menggunakannya dan yang lainnya menguasai secara pasif karena kaum remaja pada umumnya lebih menguasai bahasa melayu Manado ketimbang bahasa Tontemboan. Penggunaan bahasa Tontemboan di kalangan remaja jelaslah makin menunjukkan pergeseran bagi sebagian remaja.

Pengkajian bahasa daerah khususunya bahasa Tontemboan perlu dilakukan karena dikhawatirkan bahasa daerah ini akan mengalami pergeseran bahasa yang akan mengarah pada kepunahan bahasa seperti yang terjadi di beberapa daerah di Indonesia (Papua dan Maluku). Bahasa daerah masih memiliki kedudukan dan fungsi tertentu di Indonesia. Menurut Wojowasito dalam Halim (1981:75) bahasa daerah digunakan dalam perintah dan bercakap-cakap dengan pelayan, percakapan rutin dan akrab antar pegawai, surat menyurat dalam keluarga, sandiwara dengan tema kehidupan di daerah, majalah berkala daerah, sastra rakyat.

Selain itu untuk kepentingan penelitian bahasa daerah, peneliti tentunya membutuhkan informan bahasa daerah. Penelitian bahasa daerah khususnya struktur bahasa daerah harus dilakukan untuk kepentingan pengajaran bahasa daerah di sekolah-sekolah. Bahasa daerah masih merupakan salah satu pilihan muatan lokal bagi sekolah-sekolah di Minahasa khususnya.

Hal yang sangat penting untuk disadari oleh masyarakat pemakai bahasa daerah adalah di dalam UUD 1945 bab XV Pasal 36 ayat (2) dikatakan bahwa bahasa yang dipelihara oleh rakyatnya dengan baik-baik harus dipelihara oleh negara. Kata 'dipelihara' dapat dimaknai bahwa bahasa daerah harus digunakan karena selain menjadi aset nasional, bahasa daerah juga dapat memperkaya perbendaharaan kata bahasa Indonesia. Dengan menggunakan kata/kalimat bahasa daerah ketika berbicara dalam bahasa Indonesia, kita bangsa Indonesia telah menunjukkan sikap positif dalam berbahasa daerah.

Sejauh ini pendeskripsian tentang penggunaan bahasa Tontemboan di kalangan remaja Desa Mokobang Kecamatan Modoinding Kabupaten Minahasa Selatan belum dilakukan. Pentingnya pendeskripsian penggunaan bahasa Tontemboan ini adalah sebagai upaya menindaklanjuti upaya pemerintah dalam melestarikan, membina penggunaan bahasa Tontemboan di kalangan remaja.

Adapun tujuan penelitian yang dirumuskan: 1) Untuk mendeskripsikan bentuk pemertahanan Bahasa Tontemboan di kalangan pemuda desa Mokobang Kecamatan Modoinding Kabupaten Minahasa. 2) Untuk mendeskripsikan faktor-faktor penyebab pemertahanan bahasa Tontemboan di kalangan pemuda desa Mokobang Kecamatan Modoinding Kabupaten Minahasa Selatan dilihat dari aspek keluarga.

\section{METODE}

Metode yang digunakan dalam penelitian ini adalah metode deskriptif kualitatif, yaitu penelitian yang menjelaskan konsep-konsep dalam hubungan satu dengan yang lain dengan menggunakan katakata atau kalimat tanpa menggunakan angka-angka statistik dalam struktur yang logik serta mempergunakan pemahaman yang mendalam dimana kesemuanya itu akan dideskripsikan apa adanya sesuai pada data atau objek yang diteliti.

\section{Waktu dan Tempat Penelitian}

Penelitian ini dilakukan di Desa Mokobang Kecamatan Modoinding pada semester ganjil tahun pelajaran 2019/2020.

\section{Sumber Data Penelitian}

Sumber data penelitian ini ialah remaja berusia 17-19 tahun di Desa Mokobang Kecamatan Modoinding Kabupaten Minahasa Selatan. Persyaratan informan adalah :

- Orang tua adalah penutur bahasa Tontemboan.

- Remaja lahir dan dibesarkan di Kecamatan Modoinding. Jumlah informan adalah 20 orang yang terdiri atas : 
$\begin{array}{lll}\text { 1. Pendidikan SD } & : 5 \text { orang } \\ \text { 2. Pendidikan SMP } & : 5 \text { orang } \\ \text { 3. Pendidikan SMA } & : 10 \text { orang }\end{array}$

\section{Variabel Penelitian}

Yang menjadi variabel dalam penelitian ini ialah :

- Latar belakang pendidikan remaja

- Latar belakang keluarga remaja

- Mobilitas keluarga

\section{Teknik Pengumpulan Data}

- Teknik Simak

Teknik simak digunakan untuk menyimak penggunaan bahasa oleh remaja baik di lingkungan keluarga, teman maupun dengan anggota masyarakat lainnya. Teknik simak dapat dilakukan dengan menyadap sambil penelitian melibatkan diri dalam menggunakan bahasa Tontemboan. Teknik ini dikenal dengan teknik simak libat cakap.

- Teknik Cakap

Teknik capak digunakan dengan cara penelitian melakukan percakapan semuka dengan informan. Teknik ini disebut juga teknik cakap semuka.

- Teknik Catat

Teknik ini digunakan untuk mencatat penggunaan bahasa oleh remaja.

- Teknik Rekam

Teknik ini digunakan untuk merekam penggunaan bahasa Tontemboan oleh remaja.

\section{Teknik Analisis Data}

Data yang diperoleh melalui teknik simak, cakap, rekaman dan pencatatan di lapangan dianalisis sesuai karakter masalah dan tujuan dalam penelitian ini. Analisis data dalam penelitian ini dilakukan oleh peneliti ketika berada di lapangan sementara pengambilan data dan setelah pengambilan data berakhir. Miles dan Huberman (dalam Sugiono, 2009) mengemukakan bahwa aktivitas dalam analisis data kualitatif dilakukan secara interaktif dan berlangsung secara terus menerus sampai tuntas dan mencapai kejenuhan. Aktivitas dalam analisis data, yaitu pengurangan data 'data reduction' penyajian data dan data display dan menarik kesimpulan/purifikasi 'conclusion drawing/verification'.

Langkah-langkahnya adalah :

1. Klasifikasi data menurut pendidikan remaja yaitu SD, SMP, SMA.

2. Klasifikasi jawaban informan menurut item pertanyaan yang telah disiapkan.

3. Menghitung frekuensi penggunaan bahasa Tontemboan sesuai item pertanyaan.

4. Verifikasi data.

\section{HASIL DAN PEMBAHASAN}

Data yang dikumpulkan dari informan yang terdiri dari 20 orang berupa penggunaan bahasa oleh pemuda di desa Mokobang kecamatan Modoinding yang terdiri dari bahasa Tantemboan yang selanjutnya disingkat (BT). Bahasa melayu Manado (BMM) dan Bahasa Tantemboan dan Bahasa elayu Manado (BT-BMM). Ada beberapa situasi komunikasi berbahasa yang menjadi sumber 1 . komunikasi dengan Ayah dan Ibu; 2. Komunikasi dengan adik dan kakek; 3. Kakek atau Nenek; 4. Komunikasi dengan sesame pemuda; 5. Kominukasi dengan orang yang lebih mudah; 6. Komunikasi 
dengan orang yang lebih tua; 7. Kominikasi dengan pimpinan organisasi; 8. Kominikasi dengan pemerintah.

Untuk mendapatkan keseluruan jumlah nilai pemakaian BT, BT-BMM, dan BMM dari keseluruan informasi dapat dilihat dalam tabel berikut ini:

Jumlah Pemakaian BT, BT-BMM dan BMM

\begin{tabular}{|l|l|l|l|}
\hline Informan & BT & Campuran BT-BMM & BMM \\
\hline 1 & 0 & 37,5 & 62,5 \\
2 & 25 & 25 & 50 \\
3 & 0 & 12,5 & 87,5 \\
4 & 25 & 12,5 & 62,5 \\
5 & 0 & 12,5 & 75 \\
6 & 0 & 0 & 100 \\
7 & 0 & 25 & 75 \\
8 & 12,5 & 25 & 100 \\
9 & 0 & 25 & 75 \\
10 & 0 & 25 & 62,5 \\
11 & 0 & 25 & 75 \\
12 & 0 & 12,5 & 75 \\
13 & 0 & 12,5 & 75 \\
14 & 0 & 0 & 87,5 \\
15 & 0 & 0 & 87,5 \\
16 & 0 & 25 & 100 \\
17 & 0 & 25 & 100 \\
18 & 25 & 0 & 75 \\
19 & 0 & 25 & 72 \\
& 0 & 25 & 75 \\
\hline Total & 87,5 & 337,5 & 1475 \\
\hline
\end{tabular}

\section{KESIMPULAN}

1. BT masih bertahan ketika BT digunakan terhadap prang yang lebih tua baik akrab maupun tidak akrab, juga terhadap oran yang berusia sebaya/lebih muda dan akrab dengan remaja.

2. Faktor keluarga, pendidikan, mobilitas masyarakat menjadi penyebab bertahannya BT. 


\section{DAFTAR PUSTAKA}

Chaer, Abdul, dan Leonie Agustina, 2004. Sosiolinguistik: Perkenalan Awal. Edisi Revisi, Jakarta, PT Rineka Cipta.

Fasold, Ralph, 1984. The Sociolinguistic of Society. Oxford: Basil Blackwell.

Fishman, Joshua A (Ed), 1972a. Reading in the Sociology of Language. Paris: Mouton. Holmes, Janet, 1992. An Introduction to Sociolinguistic. New York: Longman.

Liebersoon, Stanley, 1972. Bilingualism in Montreal: A Demographic Analysis. Dalam Fishman, J.A. (Ed.), 1972. Advances in The Sociology of Language. Volume 2. Mouton: The Hagne.

Mahsun, 2007. Metode Penelitian Bahasa. Jakarta: PT Raja Grafindo Persada. Sugiyono, 2009. Metodologi Penelitian Kuantitatif Kualitatif. Bandung: Alfabeta. Sumarsono dan Paina Pratana, 2000. Sosiolinguistik. Yogyakarta: Sabda. Sumarsono, 2007. Sosiolinguistik. Yogyakarta: Pustaka Pelajar.

Wojowasito, 1981. Pengembangan Bahasa Daerah dalam Amran Halim Politik Bahasa Nasional 2. Jakarta: Balai Pusta 